\title{
Accumulation of PAH in bivalves (Crassostrea gigas andMytilus coruscus) from Zhejiang coastal,China , and associtated human health risk assessment
}

lei li

Chinese Academy of Fishery Sciences East China Sea Fishery Research Institute ziniu li

Chinese Academy of Fishery Sciences East China Sea Fishery Research Institute guodong XV

Chinese Academy of Fishery Sciences East China Sea Fishery Research Institute cuihua wang

Chinese Academy of Fishery Sciences East China Sea Fishery Research Institute mei jiang ( $\square$ jerrylee200224@126.com )

Chinese Academy of Fishery Sciences East China Sea Fishery Research Institute

Research article

Keywords: Accumulation, PAH, bivalve, health risk assessment

Posted Date: March 1st, 2021

DOl: https://doi.org/10.21203/rs.3.rs-189664/v1

License: (c) (1) This work is licensed under a Creative Commons Attribution 4.0 International License. Read Full License 


\section{Abstract}

The paper reported the determination on PAHs concentrations in bivalves (Crassostrea gigas and Mytilus coruscus) from the Zhejiang coastal of China, and evaluate their composition, and assess their human health risk. The content of $\Sigma P A H s$ in the two bivalves ranged from 48.30 to $61.08 \mathrm{ng} / \mathrm{g}$. The main component of PAHs was Phenanthrene(11.08-15.79 ng/g). Comparing with HMW-PAHs, PAHs dominated by LMW-PAHs have higher absorption rates and lower purification rates. In the local coastal environment, the pyrolytic sources were an important role of the PAH pollution. At present, it assessed the health risks on consumption the two bivalves species,there was no threat to human health by eating shellfish accumulated PAH intakes, but there were some carcinogenic risks for heavier consumption of this two bivalves. The results will provide a reference value for the shellfish living marine environment in the region.

\section{Introduction}

Polycyclic aromatic hydrocarbons (PAHs) are typical persistent organic pollutants, which are hydrophobic compounds formed by connecting two or more benzene rings in the form of fused rings or non-fused rings (Chen et al., 2015).PAHs are widely found in the marine environment, it is derived from organic matter and fossil fuels incomplete combustion, oil leakage, industrial wastes, incineration of solid wastes and so on(Kim et al., 2013).PAHs are highly toxic, carcinogenic, mutagenic, teratogenic, and interfere with endocrine effects (Stegeman,1985, Kim et al., 2013). The biomagnifications effect of PAHs is very limited by transmitting through the food chain, and organisms can enrich PAHs by absorbing PAHs in high concentration water (Barhoumi et al., 2016).With the development of the petroleum and chemical industries, all kinds of water body and aquatic organisms have been polluted by PAHs, including seawater, river water, lake water, and groundwater, which directly affect the quality and safety of human drinking water and food(Cao, 2015, Dong, 2015). Therefore, the concentration distribution of PAHs, pollution source of PAHs, and health risk assessment of PAHs have become the focus and hotspot on persistent toxic pollutants of scholars around the world on (Marrucci et al., 2013, Li et al., 2015, Chen et al., 2015).

Marine bivalve can reflect the local environmental conditions of water body due to their unique physiological and ecological characteristics. The marine mussel can be fixed on hard surfaces such as rocks by the attaching filaments, filtering water for food through the gill tissue, and ingesting other particulate matter. The marine mussels have a strong bioaccumulation effect on fat-soluble pollutants (Coughlam et al., 2002).PAHs are toxic to non-target organisms, among which marine bivalve being the most prominent these (Rantam 1997, Baussant et al., 2001).Shellfish are in the middle of the food chain, the material can transfer threatens the health of even higher organisms and even humans. The bivalve molluscs have a poor mobility, with regarded as monitoring marine chemical pollution indicator organisms, and strong pollutant enrichment capability(Le,2004). The marine mussels (Mytilus sp.), Oysters (Crassostrea virginica), and zebra mussels (Dreissena $s p$.) were regarded as model species, monitoring the hazards of chemical pollutants of marine environment, and were used to assessment human health risk with a potential threat (Geyer et al., 1982). There is widespread concern about the bioaccumulation and toxic effects of PAH in these aquatic organisms, and their further spread to humans through the food chain (Moslen, 2019). Health risk assessment is an important basis for formulating food safety policies and regulations and solving international food trade disputes. It estimates potential risk assessments scientifically and reasonably by combining pollutant 
concentrations, dietary levels, toxicological effects. As a result, some countries and the World Health Organization (WHO) have established the maximum acceptable concentration of PAHs in certain marine organisms, with beyond the acceptable concentration, the health of human consumers is compromised(ReySalgueiro et al., 2009).

Zhejiang province is located in the southeast coastal areas of China and is an important marine fishery base in China.Due to the rapid development of industry and agriculture in recent years, the land-based pollutants discharged into the sea have increased year by year, causing serious pollution such as PAH, heavy metals and so on of the coastal waters (Tientchen, 2008, Wang et al., 2015). C. gigas and M. coruscus were the most commercially valuable aquatic product species in Zhejiang Province, with high economic value and relevance to human consumption. They are a widely accepted sentinel for the study of seawater chemical pollution and biomarker related to PAH exposure (Wang et al., 2011, Barhoumi et al., 2016). Based on the above considerations, this study selected these two bivalve species and regions for research. Therefore, the purpose of this study was to determine the concentrations of PAH in $C$. gigas and $M$. coruscus obtained from the coast in Zhejiang province, China, and assessment the potential health risk concerning the two bivalve consumption. The results obtained canindicate PAHs in the environmental migration of this study area, and provide a reference value for the shellfish living marine environment in the region.

\section{Materials And Methods 2.1. Sample collection}

The bivalve( $C$. gigas and $M$. coruscus) samples were collected from fourregions (ZHOUSHAN, NINGBO, TAIZHOU and WENZHOU) along the coast of Zhejiang, China (Fig. 1). The seafood of the selected areas play a key role in the Zhejiang Province ecosystem and in providing seafood to humans. Samples were obtained every month from March to November. The samples were wrapped in aluminum foil and transported to the laboratory for analysis. The soft tissues from each spaced sample of three shellfish were immediately refrigerated $\left(-20^{\circ} \mathrm{C}\right)$ until homogenized for further extractions.

\subsection{Extraction and analysis}

The method described by Tongo (2018) was used to extract PAHs with some modifications. The homogenized bivalve samples $(10 \mathrm{~g})$ were thoroughly mixed with anhydrous $\mathrm{Na}_{2} \mathrm{SO}_{4}$ to dehydrate the sample. During extraction, $20 \mathrm{ml}$ of dichloromethane was added to the sample,which was covered with aluminum foil to prevent evaporation, and then centrifugationed to separate the supernatant of the extract. The extract was concentrated using an evaporator, and the extract was purified using a chromatographic column, and appropriately filled with $1 \mathrm{~cm}$ glass wool at the bottom. $2 \mathrm{~g}$ of silica gel and $1 \mathrm{~cm}$ of anhydrous $\mathrm{Na}_{2} \mathrm{SO}_{4}$ were added to the column, and the column was pre-eluted with $20 \mathrm{ml}$ of dichloromethane. Concentrated the extracts and then placed them in a $2 \mathrm{ml}$ vial (Frapiccini et al., 2018, Moslen, 2019). Analytical gas chromatography(HP6890Series II GC-FID, USA) was used to complete the determination of PAHs in the extracted samples. The instrumental analysis was based on the method by Tongo (2017). 
$\mathrm{PAH}$ was quantified by external standard calibration (the PAH calibration mixture was from Sigma Corporation). Quality assurance (QA) and quality control (QC)strictly monitored all analytical procedures. The method blank samples, inner indicator samples, parallel samples, and standard sample were analyzed along with every 10 samples. The relative standard deviation (RSD) of parallel samples was less than $8 \%$. Spike recoveries remained from $85-112 \%$. The method blank samples were detected no PAHs concentration. The detection limit of the method was determined 3 times than the signal-to-noise ratio with the ranged from 0.01 to $0.10 \mathrm{ng} / \mathrm{g}$.

\subsection{Risk assessment}

Human health risk assessment was conducted to estimate the possibility of exposure to PAHs through consumption of contaminated shellfish, and that could adversely affect human health. Different evaluation methods have been proposed the harms to human health of PAHs mixture in food. There are many models for assessing PAH health risks, such as exposure models, toxicity models, risk models, and thresholdless models (Ferrante et al., 2018). Halek(2007) assessed the Dietary Daily Intake of DDI of adult population by PAHs in the bivalves. In order to better assess the risk caused by the consumption of the two bivalves in this study, the average consumption rates for adults were converted based on Chinese averages $\left(24.25 \times 10^{-3} \mathrm{~kg} / \mathrm{day}\right)$ (JECFA,2019). Ding(2012) summarized the carcinogenic potencies of individual PAHs (B(A)Pteq) to derive the carcinogenic toxic equivalents (TEQs).Incremental Life Cancer Risk (ILCR) was evaluated to determine noncarcinogenic effects and carcinogenic effects (Oliveira et al., 2018).

\subsection{Data analysis}

Excel 2010 and SPSS17.0 were used for basic statistics and charts. The PAH concentrations in bivalve tissues was analyzed using the One-way analysis of variance (ANOVA) with Duncan's method. An independent sample t-test was performed to determine the significant difference between the two bivalves analyzed.

\section{Results And Discussion}

\subsection{PAH concentrations in two bivalve species ( $C$. gigas and M. coruscus)}

The quantitative results of $\mathrm{PAH}$ homologues in two bivalve species samples were showed in Table 1 from different markets of Zhejiang Province, China. The concentrations of individual PAH homologues in $M$. coruscus were greater profile, followed by $C$. gigas. ANOVA test showed that PAHs concentrations was a significantly difference in the two bivalve species $(p<0.05)$. Among individual concentrations of PAHs, Phenanthrene was the most dominant homologue of the two samples, and its concentration was significantly higher than the other homologues $(p<0.05)$.The average Phenanthrene concentrations of $C$. gigas and M.coruscus were $14.50 \pm 1.29$ and $12.33 \pm 1.25 \mathrm{ng} / \mathrm{g}$, accounting for $29.20 \%$ and $21.05 \%$ of the total PAHs, respectively. However, night specific PAHs (Acenaphthene, Anthracene, Fluorene, Fluoranthene, Benzo(a)anthracene, Benzo(k)fluoranthene, Indeno(1,2,3)pyrene, Dibenzo(a,h)anthracene and Benzo(g,h,i,)perylene) had the lowest mean concentration $(\mathrm{ng} / \mathrm{g})$ of ND in bivalve samples examined. The total carcinogenic PAH (sum of BaA, Chr, BkF, BaP, BbF, Ind, DaHA, BgP) concentrations were $9.36 \mathrm{ng} / \mathrm{g}$ and 14.60 $\mathrm{ng} / \mathrm{g}$ in $C$. gigas and M.coruscus, respectively (Table 1). The average concentrations for total carcinogenic 
PAHsin C. gigas accounted were higher (18.85\%) than that in M. coruscus, but there is no statistically significantdifference between the two concentrations $(p>0.05, \mathrm{~F}=0.26)$.

Table 1

Mean concentrations $(\mathrm{ng} / \mathrm{g}) \pm$ standard error (SE) of PAH congeners in bivalve samples examined during the study

\begin{tabular}{|c|c|c|c|c|c|c|}
\hline \multirow[t]{2}{*}{$\mathrm{PAH}(\mathrm{ng} / \mathrm{g})$} & \multirow[t]{2}{*}{ Code } & \multirow[t]{2}{*}{ Ring number } & \multicolumn{2}{|c|}{ Crassostrea gigas } & \multicolumn{2}{|c|}{ Mytilus coruscus } \\
\hline & & & Mean & $S D(n=64)$ & Mean & $\operatorname{SD}(n=64)$ \\
\hline Naphthalene & Nap & 2 & 4.77 & 0.34 & 9.52 & 0.84 \\
\hline Acenaphthene & Ace & 3 & ND & ND & ND & ND \\
\hline Acenaphthylene & Acy & 3 & 10.46 & 0.51 & 8.77 & 0.51 \\
\hline Phenanthrene & Phe & 3 & 14.50 & 1.29 & 12.33 & 1.25 \\
\hline Anthracene & Ant & 3 & ND & ND & ND & ND \\
\hline Fluorene & Flu & 4 & ND & ND & ND & ND \\
\hline Fluoranthene & $\mathrm{FI}$ & 4 & ND & ND & ND & ND \\
\hline Pyrene & Pyr & 4 & 10.56 & 0.92 & 13.35 & 1.78 \\
\hline Benzo(a)anthracene & $\mathrm{BaA}$ & 4 & ND & ND & ND & ND \\
\hline Chrysene & Chr & 4 & 4.82 & 0.83 & 7.34 & 0.29 \\
\hline Benzo(k)fluoranthene & $\mathrm{BkF}$ & 5 & ND & ND & ND & ND \\
\hline Benzo(b)fluoranthene & $\mathrm{BbF}$ & 5 & 1.03 & 0.04 & 1.09 & 0.03 \\
\hline Benzo(a)pyrene & $\mathrm{BaP}$ & 5 & 3.51 & 0.02 & 6.17 & 0.09 \\
\hline Indeno(1,2,3)pyrene & Ind & 6 & ND & ND & ND & ND \\
\hline Dibenzo(a,h)anthracene & DaHA & 6 & ND & ND & ND & ND \\
\hline Benzo(g,h,i,)perylene & $\mathrm{BgP}$ & 6 & ND & ND & ND & ND \\
\hline Total PAH & $\Sigma \mathrm{PAH}$ & & 49.65 & 1.35 & 58.57 & 2.51 \\
\hline Total carcinogenic PAH & $\Sigma \mathrm{CPAH}$ & & 9.36 & 0.88 & 14.60 & 0.39 \\
\hline
\end{tabular}

European Food Safety Authority (EFSA) regards that BaP is not a suitable marker for PAHs in food. The system of two specific PAHs ( $(\mathrm{PAHs} 2=\mathrm{BaP}+$ Chy $)$ or four specific PAHs $(\Sigma \mathrm{PAHs} 4=\mathrm{BaP}+\mathrm{BaA}+\mathrm{BbF}+\mathrm{Chy})$ or eight specific PAHs ( $\sum$ PAHs8 $\left.=\Sigma P A H s 4+B k F+B g h i P+D a h A+I n d\right)$ will be the suitable indicators food for $\mathrm{PAH}$, and maintain a separate maximum level for BaP (Ferrante et al., 2018). For two bivalve species, the descriptive statistic were detected in Table 2, which was expressed in $\mathrm{ng} / \mathrm{g}$, for PAH2, PAH4, PAH8, PAH16. The same phenomenon was observed in the sum of $\sum \mathrm{PAH} 2, \sum \mathrm{PAH} 4, \sum \mathrm{PAH} 8$ and $\sum \mathrm{PAH} 16$, which were significantly higher than two bivalve species $(p<0.05)$. There was no significant difference among concentrations of PAH2 and PAH4 and PAH8 components $(p<0.05)$, which is due to the lowest concentrations 
of BaA, BkF, BghiP, DahA, Ind(Table 2). In the present study we foundPAHs8 did not provide much added value, which was consistent with the discovery of two bivalve species with little difference between PAH4 and PAH8 (Moslen, 2019). The concentrations of PAH4 and PAH8 in the two bivalves were lower than the regulatory maximum value of PAH4 (30 $\mu \mathrm{g} / \mathrm{kg}$ ) for European Commission Regulation (EU) No 835/2011. This indicated that lower risk of carcinogenic potentials for people with consuming the two bivalves on the present study region.

Table 2

PAH2, PAH4, PAH8 and PAH16 concentrations ( $\mathrm{ng} / \mathrm{g})$ in bivalve

\begin{tabular}{|llllll|}
\hline Bivalve & & PAH2 & $\sum$ PAH4 & $\sum$ PAH8 & $\sum$ PAH16 \\
\hline \multirow{2}{*}{ Crassostrea gigas } & Mean & 8.33 & 9.36 & 9.36 & 49.65 \\
\cline { 2 - 6 } & Range & $2.57 \sim 15.28$ & $3.12 \sim 17.65$ & $3.12 \sim 17.65$ & $48.30 \sim 69.13$ \\
\cline { 2 - 6 } & S.D. & 1.29 & 1.68 & 1.68 & 1.35 \\
\hline Mytilus coruscus & Mean & 13.51 & 14.60 & 14.60 & 58.87 \\
\cline { 2 - 6 } & Range & $10.48 \sim 19.34$ & $9.82 \sim 18.66$ & $9.82 \sim 18.66$ & $35.44 \sim 98.65$ \\
\cline { 2 - 6 } & S.D. & 2.47 & 2.64 & 2.64 & 2.51 \\
\hline
\end{tabular}

In order to know the compositions and sources of PAH pollution, 16 priority PAHs and 2-, 3-, 4-, 5-, and 6-ring compounds were analyzed in the present study. The lower molecular weight PAHs (LMW) (two to three rings)average concentration of in two bivalve samples were lower than higher molecular weight PAHs (HMW) (four tosix rings), accounting for $51.60-59.88 \%$ of the total PAH, respectively (Fig. 2). There was no significant difference between the two bivalves samples $(p>0.05)$. It was similar to the PAH profile of mussels collected from the Corral Bay of South Central Chile and the Bizerte lagoon of Tunisia, which was reported by Palma-Fleming et al. (2012) and Barhoumi et al. (2014), respectively. The ratio of low molecular PAHs (two to three rings) to high molecular PAHs (four to six rings) was utilized to predict the pollution sources of different congeners, In general, LMW/HMW $>1$ indicates the petrogenic origin, whereas $\mathrm{LMW} / \mathrm{HMW}<1$ indicates the sources of pyrolytic (Yunker et al., 2002). The LMW/HMW ratios obtained for this study was greater than 1 , indicating that the PAH of all the samples examined were derived from pyrolysis. The concentration of pollutants in the environment and the physiological and ecological characteristics of shellfish will affect the concentration of pollutants in shellfish (Yim, 2007). Crustaceans are particularly susceptible to contamination because of the reduced bioavailability of PAHs in these species (Law et al., 2002). These four areas were located in the main freight ports of Zhejiang Province, with a large number of cargo ships. The LMW PAHs accumulate in living organisms, which may be related to frequent marine transportation of ships and fuel leaks because of LMW PAHs are mainly derived from crude oil (Haruhiko et al., 2003).This can explain why levels of LMW PAHs in these two bivalves is higher .

For assessment the degree of PAH pollution of the study area, it is necessary to comparison it with other regional studies, in which PAH concentrations in bivalves had been also measured. The concentrations of PAHs in bivalves samples were obtained from different areas were summarized in Table 3. Compared with other marine bivalves, the current results were far lower than the mussels collected from Bizerte lagoon(107.4- 
$430.7 \mathrm{ng} / \mathrm{g})$, and the mussels collected from Tunisia Mediterranean Sea $(146.9 \mathrm{ng} / \mathrm{g})$, which were two highly polluted areas. On the other hand, PAH concentrations are very different to those measured in bivalves samples collected from the Hainan Island (China), and were similar to that of mussel in the Gulf of Naples, Italy $(77.69 \pm 9.18 \mathrm{ng} / \mathrm{g})$. The PAHs concentrations of the two bivalve species were higher than that from shellfish in Nigeria (3 to $16 \mathrm{ng} / \mathrm{g}$ ). Above all, PAH concentrations of the two bivalves of Zhejiang Province are the medium pollution level compared with the reports from the other areas.

Table 3

Total PAHs in bivalves reported by other studies around the world

\begin{tabular}{|lll|}
\hline Bivalve & Total PAH & Reference \\
\hline Mytilus galloprovincialis & $77.69 \pm 9.18 \mathrm{ng} / \mathrm{g}$ & Perugini et al. (2007) \\
\hline Mytilus galloprovincialis & $146.9 \mathrm{ng} / \mathrm{g}$ & Mzoughi and Chouba(2012) \\
\hline Mytilus galloprovincialis & $107.4 \sim 430.7 \mathrm{ng} / \mathrm{g}$ & Barhoumi et al.(2016) \\
\hline Perna viridis & $597.1 \sim 2332 \mathrm{ng} / \mathrm{g}$ & Wang et al.(2020) \\
\hline Pinctada martensii & $818.5 \sim 215 \mathrm{ng} / \mathrm{g}$ & Wang et al.(2020) \\
\hline Arca senilis & $3-16 \mathrm{ng} / \mathrm{g}$ & Moslen(2019) \\
\hline Crassostrea gigas & $48.30 \sim 51.00 \mathrm{ng} / \mathrm{g}$ & This study \\
\hline Mytilus coruscus & $56.06 \sim 61.38 \mathrm{ng} / \mathrm{g}$ & This study \\
\hline
\end{tabular}

\subsection{Human health risk assessment of PAH in bivalve}

C. gigasand M. coruscus were regarded as the suitable indicator organisms which could monitor environmental pollution and analyzing the situation of human contact the pollutants through food, as the two bivalve species are consumed generally in Zhejiang Province. Health risk is mainly caused by the consumption of contaminated seafood. For PAH risk assessment of these two bivalve species, the risk of noncarcinogenic and carcinogenic exposure to PAHs in the diet were estimated (Table 4). The results were calculated based on the amount of PAHs by the daily ( $\mathrm{mg} / \mathrm{kg}$ bodyweight/day) amount of shellfish consumption of adult (bodyweight:70kg). 
Table 4

Estimated Dietary daily intake (DDI), Carcinogenic potencies (B(A)Pteq), and Excess cancer risk (ILCR) of PAHs in bivalve species from markets in Zhejiang coastal, China

\begin{tabular}{|c|c|c|c|c|c|c|c|c|c|}
\hline \multirow[t]{3}{*}{ PAH } & & \multirow[t]{3}{*}{ TEF } & \multirow[t]{3}{*}{ RID } & \multicolumn{2}{|c|}{ Crassostrea gigas } & \multicolumn{3}{|c|}{ Mytilus coruscus } & \multirow{3}{*}{$\begin{array}{l}\text { ILCR } \\
(\mathrm{mg} / \mathrm{kg})\end{array}$} \\
\hline & & & & DDI & B(A)Pteq & ILCR & DDI & B(A)Pteq & \\
\hline & & & & (ng/g/day) & (ng/kg) & $(\mathrm{mg} / \mathrm{kg})$ & (ng/g/day) & (ng/kg) & \\
\hline * & Nap & 0.001 & 0.02 & 115.67 & 4.77 & $\begin{array}{l}7.08 x \\
10^{-13}\end{array}$ & 230.86 & 9.52 & $\begin{array}{l}1.41 x \\
10^{-12}\end{array}$ \\
\hline * & Ace & 0.001 & 0.06 & ND & ND & ND & ND & ND & ND \\
\hline * & Acy & 0.001 & 0.06 & 253.66 & 10.46 & $\begin{array}{l}1.55 x \\
10^{-12}\end{array}$ & 212.67 & 8.77 & $\begin{array}{l}1.30 x \\
10^{-12}\end{array}$ \\
\hline * & Phe & 0.001 & 0.03 & 351.63 & 14.50 & $\begin{array}{l}2.15 x \\
10^{-12}\end{array}$ & 299.00 & 12.33 & $\begin{array}{l}1.83 x \\
10^{-12}\end{array}$ \\
\hline * & Ant & 0.01 & 0.30 & ND & ND & ND & ND & ND & ND \\
\hline * & Flu & 0.001 & 0.04 & ND & ND & ND & ND & ND & ND \\
\hline * & $\mathrm{FI}$ & 0.001 & 0.04 & ND & ND & ND & ND & ND & ND \\
\hline * & Pyr & 0.001 & 0.03 & 256.08 & 10.56 & $\begin{array}{l}1.57 x \\
10^{-12}\end{array}$ & 323.74 & 13.35 & $\begin{array}{l}1.98 x \\
10^{-12}\end{array}$ \\
\hline 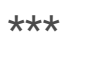 & $\mathrm{BaA}$ & 0.1 & 0.03 & ND & ND & ND & ND & ND & ND \\
\hline$\star \star \star$ & Chr & 0.01 & 0.03 & 116.89 & 48.2 & $\begin{array}{l}7.15 \times \\
10^{-12}\end{array}$ & 178.00 & 73.4 & $\begin{array}{l}1.09 x \\
10^{-11}\end{array}$ \\
\hline ** & $\mathrm{BkF}$ & 0.1 & 0.03 & ND & ND & ND & ND & ND & ND \\
\hline$\star \star \star$ & $\mathrm{BbF}$ & 1 & 0.03 & 24.98 & 1030 & $\begin{array}{l}1.53 x \\
10^{-11}\end{array}$ & 26.43 & 1090 & $\begin{array}{l}1.62 x \\
10^{-12}\end{array}$ \\
\hline$\star \star \star$ & $\mathrm{BaP}$ & 0.1 & 0.03 & 85.12 & 351 & $\begin{array}{l}5.21 x \\
10^{-11}\end{array}$ & 149.62 & 617 & $\begin{array}{l}9.16 x \\
10^{-11}\end{array}$ \\
\hline ** & Ind & 0.1 & 0.03 & ND & ND & ND & ND & ND & ND \\
\hline ** & DaHA & 5 & 0.03 & ND & ND & ND & ND & ND & ND \\
\hline$\star \star$ & $\mathrm{BgP}$ & 0.01 & 0.03 & ND & ND & ND & ND & ND & ND \\
\hline \multicolumn{10}{|c|}{$\begin{array}{l}\text { Note: TEFvaluesforthePAHswasadoptedfrom(Nisbet and LaGoy ,1992).*Non- } \\
\text { CarcinogenicPAHs. }{ }^{*} \text { CarcinogenicPAHs. }{ }^{* *} \text { CarcinogenicPAHandPAHusedtoderivethePAH4Index }\end{array}$} \\
\hline & rations & & & & & & & & \\
\hline
\end{tabular}

The dietary daily intake (DDI) was determined human health risk by consumption of pollution bivalves. The DDI of individual PAHs of $C$. ranged from 24.98 to $351.63 \mathrm{ng} /$ day, while the DDI was varied from 26.43 to $323.74 \mathrm{ng} /$ day on M. coruscus (Table 4). The DDI of individual PAHs wa susually lower than the available 
reference oral dose, and the DDI value of carcinogenic PAH was higher than that of individual PAHs. The recommended daily intake of $\mathrm{BaP}$ is $10 \mathrm{ng} / \mathrm{kg} /$ day (JECFA, 2019), which is above the DDI concentration of carcinogenic and non carcinogenic PAHs observed in this study. These levels were also lower than those reported on ingestion of bivalve (Arca senilis- blood cockles) in Nigeria population (Moslen et al., 2019). The results indicated that the consumption of M. coruscus will result in higher risk of exposure to PAHs and carcinogenic PAHs than consumption of $C$. gigas.

The carcinogenic of individual PAH in two bivalve species was different, the (B(A)Pteq of individual PAHs varied from 4.77 to $1090 \mathrm{mg} / \mathrm{kg}$ (Table 4). These values were higher than those observed for Arca senilis in Nigeria (Moslen et al., 2019).Benzo(b)fluoranthene had the highest carcinogenicpotency in C. gigas (1030 $\mathrm{mg} / \mathrm{kg}$ ) and $M$. coruscus (1090 mg/kg), which could be a concern that the shellfish alone consumed can not cause the toxic effects of PAHs to the human health (Tongo,2017).

For cancer risk, the ILCR values of the two bivalve species calculated by the China average ingestion rate were less than $10^{-10}\left(7.08 \times 10^{-13}-9.16 \times 10^{-11}\right)$ (Table 4), which is below the ILCR concentration observed in Hainan Island, China(Wang et al.,2020). The excess lifetime cancer risk of $\geq 10^{-6}$ was considered an acceptable level, while the cancer risk of $\geq 10^{-4}$ was regarded as a serious level (Mana et al.,2013).Overall, the highest contributors to ILCR are BbF and BaP, which are far below the results of other studies (Wang et al.,2020; Moslen et al., 2019). As a result, consumption of $C$. gigas and M. coruscus appears to pose an acceptable risk of cancer.

The present study investigated the PAHs content in the two bivalve species of $C$. gigas and $M$. coruscus from the Zhejiang coastal in China. Our data suggested that high rates of PAHs bioaccumulation in shellfish may be due to marine pollution, which has been examined though the potential health risks by consumption. The concentrations of single PAH homologs and total PAH in the two bivalve samples were minimal compared to regulatory maximum level. However, it was observed that the PAHs dominated by LMW-PAHs are very similar for the two bivalve samples. Compared with HMW-PAHs, the LMW-PAHs have higher water solubility, higher absorption rate and lower purification rates.Furthermore, it should be emphasized that the pyrolytic sources played an important role in PAH pollution of the local coastal environment by the analysis on the proportion of specific PAH compounds. Health index such as DDI, TEQ and ILCR were assessed, respectively. Although the two bivalves have not a potential non-carcinogenic risk, carcinogenic risks may exist for large consumption. However, with protection the public health, human health risks need to be assessed and it is essential to identify as a potential risk of PAHs by consumption the two bivalves.

\section{Declarations}

\section{Acknowledgments}

This work was supported by National Key Research and Development Project (2017YFC1600705), the earmarked fund for China Agriculture Research System (No.CARS-49), Natural Science Foundation of Shanghai(18ZR1450000), Central Public-interest Scientific Institution Basal Research Fund, CAFS (No.2020TD14). 


\section{Conflict of Interest}

No conflict of interest exits in the submission of this manuscript, and manuscript is approved by all authors for publication.

\section{References}

Barhoumi B, El Megdiche Y, Clérandea, C, et al. 2016,Occurrence of polycyclic aromatic hydrocarbons (PAHs) in mussel (Mytilus galloprovincialis) and eel (Anguilla anguilla) from Bizerte lagoon, Tunisia, and associated human health risk assessment. Cont. Shelf. Res., 124:104-116.

Barhoumi B, Le Menach K, Clerandeau C, et al. 2014, Assessment of pollution in the Bizerte lagoon (Tunisia) by the combined use of chemical and biochemical markers in mussels, Mytilus galloprovincialis. Mar. Pollut. Bull. 84: 379-390.

Baussant T, Sanni S, Jonsson G, et al. 2001,Bioaccumulation of polycyclic aromatic compounds: 1. Bioconcentration in two marine species and in semipermeable membrane devices during chronic exposure to dispersed crude oil. Environ. Toxicol. Chem. 20: 1175-1184.

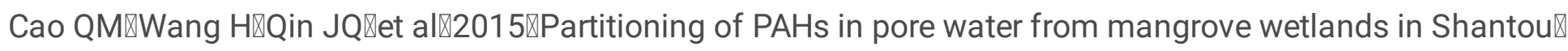
China区Ecotox. Environ. Safety. 111: 42-47区

Chen R, Lv JG, Zhang W, et al $\ 2015$, Polycyclic aromatic hydrocarbon (PAH) pollution in agricultural soil in Tianjin囚China: a spatio-temporal comparison study. Environ. Earth Sci. 74:2743-2748囚

Coughlan BM, Hartl MGJ, O'reilly SJ, et al. 2002, Detecting genotoxicity using the Comet assay following chronic exposure of Manila clam Tapes semidecussatus to polluted estuarine sediments. Mar. Pollut. Bull. 44: $1359-1365$.

Ding C, Ni H, Zeng H. 2012, Parent and halogenated polycyclic aromatic hydrocarbons in rice and implications for human health in China. Environ. Pollut. 168:80-86.

Dong WH,Lin XY,Du SH,et al『2015,Risk assessment of organic contamination in shallow ground water around

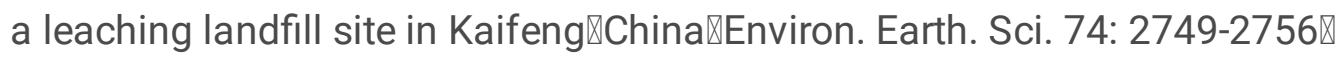

Fang JKH, Wu RSS, Zheng GJ, et al. 2009, The use of muscle burden in rabbitfish Siganus oramin for monitoring polycyclic aromatic hydrocarbons and polychlorinated biphenyls in Victoria Harbour, Hong Kong and potential human health risk.Sci.Total Environ. 407 :4327-4332.

Fang. 2007, Persistent Organie Pollutants and Heavy Metals in Surface Sediments and Marine organisms from Coastal Areas of Zhejiang province. Zhejiang university(in Chinese).

Ferrante M, Zangh G, Cristaldi A, et al. 2018, PAHs in seafood from the Mediterranean Sea: An exposure risk assessment. Food. Chem. Toxicol. 115:385-390. 
Frapiccini E, Annibaldi A, Betti M, et al. 2018, Polycyclic aromatic hydrocarbon (PAH) accumulation in different common sole (Solea solea) tissues from the North Adriatic Sea peculiar impacted area. Mar. Pollut. Bull. 137:61-68.

Geyer H, Sheehan P, Kotzias D, et al. 1982,Prediction of ecotoxicological behaviour of chemicals: Relationship between physico-chemical properties and bioaccumulation of organic chemicals in the mussel Mytilus edulis. Chem.11: 1121-1134

Halek F, Nabi G, Kavousi A.2007, Polycyclic aromatic hydrocarbons study andtoxic equivalency factor (TEFs) in Tehran, Iran, Environ. Monit. Assess. 143:303-311.

Harris SA, Jones JL. 2008, Fish consumption and pcb-associated health risks in recreational fishermen on the James River, Virginia. Environ. Res. 107:254-263.

Haruhiko N, Yasufumi S, Takashi MA, et al. 2003, Bioaccumulation and toxic potencies of polychlorinated biphenyls and polycyclic aromatic hydrocarbons in tidal flat and coastal ecosystems of the Ariake Sea, Japan. Environ. Sci. Tech. 37:3513-3521

JECFA, 2019. Evaluations of the joint FAO/WHO expert committee on food additives.Available at: http://apps.who.int/food-additives-contaminants-jecfa-database/chemical.aspx?chemID=4306

Kim KH, Jahan SA, Kabir E, et al. 2013, A review of airborne polycyclic aromatic hydrocarbons (PAHs) and their human health effects. Environ. Int. 60:71-80.

Law RJ, Kelly C, Baker K, et al. 2002,Toxic equivalency factors for PAH and their applicability in shellfish pollution monitoring studies. Environ. Monit. 4:383-388.

Le Bris H, Pouliquen H. 2004, Experimental study on the bioaccumulation of oxytetracycline and oxolinic acid by the blue mussel (Mytilus edulis). An evaluation of its ability to bio-monitor antibiotics in the marine environment. Mar. Pollut. Bull. 48: 434-440.

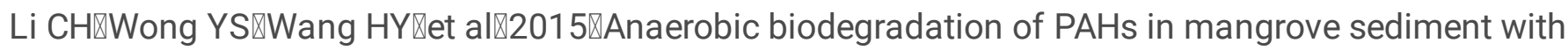
amendment of Na HCO3囚Journal of Environmental Sciences $₫ 30$ : 148-156》

Mana YB, Kangb Y, Wang HS, et al. 2013, Cancer risk assessments of Hong Kong soils contaminated by polycyclic aromatic hydrocarbons, J. Haz. Mat. 261:770-776.

Marrucci A囚Marras B $₫$ Campisi SS $₫$ et al $₫ 2013 \rrbracket$ Using SPMDs to monitor the seawater concentrations of PAHs and PCBs in marine protected areas (Western Mediterranean)囚Mar. Pollut. Bull. 75 : 69-75区

Moslen M, Miebaka CA, Boisa N.2019,Bioaccumulation of Polycyclic Aromatic Hydrocarbon (PAH) in a bivalve (Arca senilis- blood cockles) and health risk assessment. Toxico. Rep. 6:990-997

Mzoughi N, Chouba L. 2012, Heavy metals and PAH assessment based on mussel caging in the North Coast of Tunisia (Mediterranean Sea). Int. J. Environ. Res. 6:109-118. 
Nisbet I, LaGoy P. 1992, Toxic equivalency factors (TEFs) for polycyclic aromatic hydrocarbons (PAHs), Regul. Toxicol. Pharmacol. 16:290-300.

Oliveira M, Gomes F, Torrinha Á, et al. 2018,Commercial octopus species from different geographical origins: levels of polycyclic aromatic hydrocarbons and potential health risks for consumers. Food Chem. Toxicol. 121:272-282.

Palma-Fleming H, Quiroz RE, Campillay C, et al. 2012,Temporal and spatial trends of total aliphatic hydrocarbons of diesel range and trace elements in sediments and mussels of the Corral Bay Area, Valdivia, South Central Chile. J. Chil. Chem. Soc. 57:1074-1082.

Perugini M, Visciano P, Manera M, et al. 2007,Polycyclic aromatic hydrocarbons in marine organisms from the Gulf of Naples, Tyrrhenian Sea. J. Agric. Food Chem. 55:2049-2054.

Rantam KP. 1997, Release and retention of selected polycyclic aromatic hydrocarbons (PAH) and their methylated derivatives by the common mussel (Mytilus edulis) in the brackish water of the Baltic Sea. Chemosphere. 35: 487-502.

Rey-Salgueiro L, Martínez-Carballo E, García-Falcón MS, et al. 2009, Survey of polycyclic aromatic hydrocarbons in canned bivalves and investigation of their potential sources. Food Res. Int. 42: 983-988.

Stegeman JJ. 1985, Benzo [a] pyrene oxidation and microsomal enzyme activity in the mussel (Mytilus edulis) and other bivalve mollusc species from the Western North Atlantic. Mar. Bio. 89: 21-30.

Tientchen CM. 2008, Heavy Metals and PAHs in Sewage Sludge from Twelve Wastewater Treatment Plants in Zhejiang Province. Biom. Environ. Sci.4:79-86.

Tongo I, Etor IEE, Ezemonye LIN. 2018, Human health risk assessment of PAHs in fish and shellfish from amariaria community, Bonny River, Nigeria, J. Appl. Sci. Environ. Manage. 22 :731-736.

Tongo I, Ogbeide O, Ezemonye L. 2017, Human health risk assessment of polycyclic aromatic hydrocarbons (PAHs) in smoked fish species from markets in Southern Nigeria. Toxicol. Rep. 4:55-61.

Wang HH, Huang W, Gong Y, et al. 2020, Occurrence and potential health risks assessment of polycyclic aromatic hydrocarbons (PAHs) in different tissues of bivalves from Hainan Island囚China. Food. Chem. Toxicol. 136:111-108

Wang L, Pan L, Liu N, et al. 2011, Biomarkers and bioaccumulation of clam Ruditapes philippinarum in response to combined cadmium and benzop[a]pyrene exposure. Food Chem. Toxicol. 49:3407-3417.

Wang X, Xu H, Zhou Y, et al. 2015, Distribution and source apportionment of polycyclic aromatic hydrocarbons in surface sediments from Zhoushan Archipelago and Xiangshan Harbor, East China Sea. Mar. Pollut. Bull. 101:895-902.

Yim UH, Hong SH, Shim WJ. 2007, Distribution and characteristics of PAHs in sediments from the marine environment of Korea. Chemosphere. 68:85-92. 
Yunker MB, Macdonald RW, Vingarzan R, et al. 2002, PAHs in the Fraser River basin: a critical appraisal of $\mathrm{PAH}$ ratios as indicators of PAH source and composition. Org. Geochem. 33:489-515.

\section{Tables}

Table 1 Mean concentrations (ng/g) \pm standard error (SE) of PAH congeners in bivalve samples examined during the study

\begin{tabular}{|c|c|c|c|c|c|c|}
\hline \multirow[t]{2}{*}{$\mathrm{PAH}(\mathrm{ng} / \mathrm{g})$} & \multirow[t]{2}{*}{ Code } & \multirow[t]{2}{*}{ Ring number } & \multicolumn{2}{|c|}{ Crassostrea gigas } & \multicolumn{2}{|c|}{ Mytilus coruscus } \\
\hline & & & Mean & $\mathrm{SD} \square \mathrm{n}=64 \square$ & Mean & $\mathrm{SD} \square \mathrm{n}=64 \square$ \\
\hline Naphthalene & Nap & 2 & 4.77 & 0.34 & 9.52 & 0.84 \\
\hline Acenaphthene & Ace & 3 & ND & ND & ND & ND \\
\hline Acenaphthylene & Acy & 3 & 10.46 & 0.51 & 8.77 & 0.51 \\
\hline Phenanthrene & Phe & 3 & 14.50 & 1.29 & 12.33 & 1.25 \\
\hline Anthracene & Ant & 3 & ND & ND & ND & ND \\
\hline Fluorene & Flu & 4 & ND & ND & ND & ND \\
\hline Fluoranthene & $\mathrm{Fl}$ & 4 & ND & ND & ND & ND \\
\hline Pyrene & Pyr & 4 & 10.56 & 0.92 & 13.35 & 1.78 \\
\hline Benzo(a)anthracene & $\mathrm{BaA}$ & 4 & ND & ND & ND & ND \\
\hline Chrysene & $\mathrm{Chr}$ & 4 & 4.82 & 0.83 & 7.34 & 0.29 \\
\hline Benzo(k)fluoranthene & $\mathrm{BkF}$ & 5 & ND & ND & ND & ND \\
\hline Benzo(b)fluoranthene & $\mathrm{BbF}$ & 5 & 1.03 & 0.04 & 1.09 & 0.03 \\
\hline Benzo(a)pyrene & $\mathrm{BaP}$ & 5 & 3.51 & 0.02 & 6.17 & 0.09 \\
\hline Indeno $(1,2,3)$ pyrene & Ind & 6 & ND & ND & ND & ND \\
\hline Dibenzo(a,h)anthracene & DaHA & 6 & ND & ND & ND & ND \\
\hline Benzo $(g, h, i$,$) perylene$ & $\mathrm{BgP}$ & 6 & ND & ND & ND & ND \\
\hline Total PAH & $\Sigma \mathrm{PAH}$ & & 49.65 & 1.35 & 58.57 & 2.51 \\
\hline Total carcinogenic PAH & $\Sigma \mathrm{CPAH}$ & & 9.36 & 0.88 & 14.60 & 0.39 \\
\hline
\end{tabular}

Table 2 PAH2, PAH4, PAH8 and PAH16 concentrations (ng/g) in bivalve

\begin{tabular}{llllll}
\hline Bivalve & & $\sum$ PAH2 & $\sum$ PAH4 & $\sum$ PAH8 & $\sum$ PAH16 \\
\hline Crassostrea gigas & Mean & 8.33 & 9.36 & 9.36 & 49.65 \\
& Range & $2.57 \sim 15.28$ & $3.12 \sim 17.65$ & $3.12 \sim 17.65$ & $48.30 \sim 69.13$ \\
& S.D. & 1.29 & 1.68 & 1.68 & 1.35 \\
Mytilus coruscus & Mean & 13.51 & 14.60 & 14.60 & 58.87 \\
& Range & $10.48 \sim 19.34$ & $9.82 \sim 18.66$ & $9.82 \sim 18.66$ & $35.44 \sim 98.65$ \\
& S.D. & 2.47 & 2.64 & 2.64 & 2.51 \\
\hline
\end{tabular}

Table 3 Total PAHs in bivalves reported by other studies around the world 


\begin{tabular}{lll}
\hline Bivalve & Total PAH & Reference \\
\hline Mytilus galloprovincialis & $77.69 \pm 9.18 \mathrm{ng} / \mathrm{g}$ & Perugini et al. (2007) \\
Mytilus galloprovincialis & $146.9 \mathrm{ng} / \mathrm{g}$ & Mzoughi and Chouba(2012) \\
Mytilus galloprovincialis & $107.4 \sim 430.7 \mathrm{ng} / \mathrm{g}$ & Barhoumi et al.(2016) \\
Perna viridis & $597.1 \sim 2332 \mathrm{ng} / \mathrm{g}$ & Wang et al.(2020) \\
Pinctada martensii & $818.5 \sim 215 \mathrm{ng} / \mathrm{g}$ & Wang et al.(2020) \\
Arca senilis & $3-16 \mathrm{ng} / \mathrm{g}$ & Moslen(2019) \\
Crassostrea gigas & $48.30 \sim 51.00 \mathrm{ng} / \mathrm{g}$ & This study \\
Mytilus coruscus & $56.06 \sim 61.38 \mathrm{ng} / \mathrm{g}$ & This study \\
\hline
\end{tabular}

Table 4 Estimated Dietary daily intake (DDI), Carcinogenic potencies (B(A)Pteq), and Excess cancer risk (ILCR) of PAHs in bivalve species from markets in Zhejiang coastal, China

\begin{tabular}{|c|c|c|c|c|c|c|c|c|c|}
\hline \multicolumn{2}{|c|}{$\mathrm{PAH}$} & \multirow[t]{2}{*}{ TEF } & \multirow[t]{2}{*}{ RID } & \multicolumn{3}{|c|}{ Crassostrea gigas } & \multicolumn{3}{|c|}{ Mytilus coruscus } \\
\hline & & & & $\begin{array}{c}\text { DDI } \\
\text { (ng/g/day) }\end{array}$ & $\begin{array}{c}\text { B(A)Pteq } \\
(\mathrm{ng} / \mathrm{kg})\end{array}$ & $\begin{array}{c}\text { ILCR } \\
(\mathrm{mg} / \mathrm{kg})\end{array}$ & $\begin{array}{c}\text { DDI } \\
\text { (ng/g/day) }\end{array}$ & $\begin{array}{c}\text { B(A)Pteq } \\
\text { (ng/kg) }\end{array}$ & $\begin{array}{c}\text { ILCR } \\
(\mathrm{mg} / \mathrm{kg})\end{array}$ \\
\hline * & Nap & 0.001 & 0.02 & 115.67 & 4.77 & $7.08 \times 10^{-13}$ & 230.86 & 9.52 & $1.41 \times 10^{-12}$ \\
\hline$*$ & Ace & 0.001 & 0.06 & ND & ND & ND & ND & ND & ND \\
\hline$*$ & Acy & 0.001 & 0.06 & 253.66 & 10.46 & $1.55 \times 10^{-12}$ & 212.67 & 8.77 & $1.30 \times 10^{-12}$ \\
\hline$*$ & Phe & 0.001 & 0.03 & 351.63 & 14.50 & $2.15 \times 10^{-12}$ & 299.00 & 12.33 & $1.83 \times 10^{-12}$ \\
\hline$*$ & Ant & 0.01 & 0.30 & ND & ND & ND & ND & ND & ND \\
\hline$*$ & Flu & 0.001 & 0.04 & ND & ND & ND & ND & ND & ND \\
\hline$*$ & $\mathrm{Fl}$ & 0.001 & 0.04 & ND & ND & ND & ND & ND & ND \\
\hline$*$ & Pyr & 0.001 & 0.03 & 256.08 & 10.56 & $1.57 \times 10^{-12}$ & 323.74 & 13.35 & $1.98 \times 10^{-12}$ \\
\hline$* * *$ & $\mathrm{BaA}$ & 0.1 & 0.03 & ND & ND & ND & ND & ND & ND \\
\hline$* * *$ & Chr & 0.01 & 0.03 & 116.89 & 48.2 & $7.15 \times 10^{-12}$ & 178.00 & 73.4 & $1.09 \times 10^{-11}$ \\
\hline$* *$ & $\mathrm{BkF}$ & 0.1 & 0.03 & ND & ND & ND & ND & ND & ND \\
\hline$* * *$ & $\mathrm{BbF}$ & 1 & 0.03 & 24.98 & 1030 & $1.53 \times 10^{-11}$ & 26.43 & 1090 & $1.62 \times 10^{-12}$ \\
\hline$* * *$ & $\mathrm{BaP}$ & 0.1 & 0.03 & 85.12 & 351 & $5.21 \times 10^{-11}$ & 149.62 & 617 & $9.16 \times 10^{-11}$ \\
\hline$* *$ & Ind & 0.1 & 0.03 & ND & ND & ND & ND & ND & ND \\
\hline$* *$ & DaHA & 5 & 0.03 & ND & ND & ND & ND & ND & ND \\
\hline$* *$ & $\mathrm{BgP}$ & 0.01 & 0.03 & ND & ND & ND & ND & ND & ND \\
\hline
\end{tabular}

Note: TEFvaluesforthePAHswasadoptedfrom(Nisbet and LaGoy ,1992).*Non-

CarcinogenicPAHs. ${ }^{* *}$ CarcinogenicPAHs. ${ }^{* * *}$ CarcinogenicPAHandPAHusedtoderivethePAH4Index 


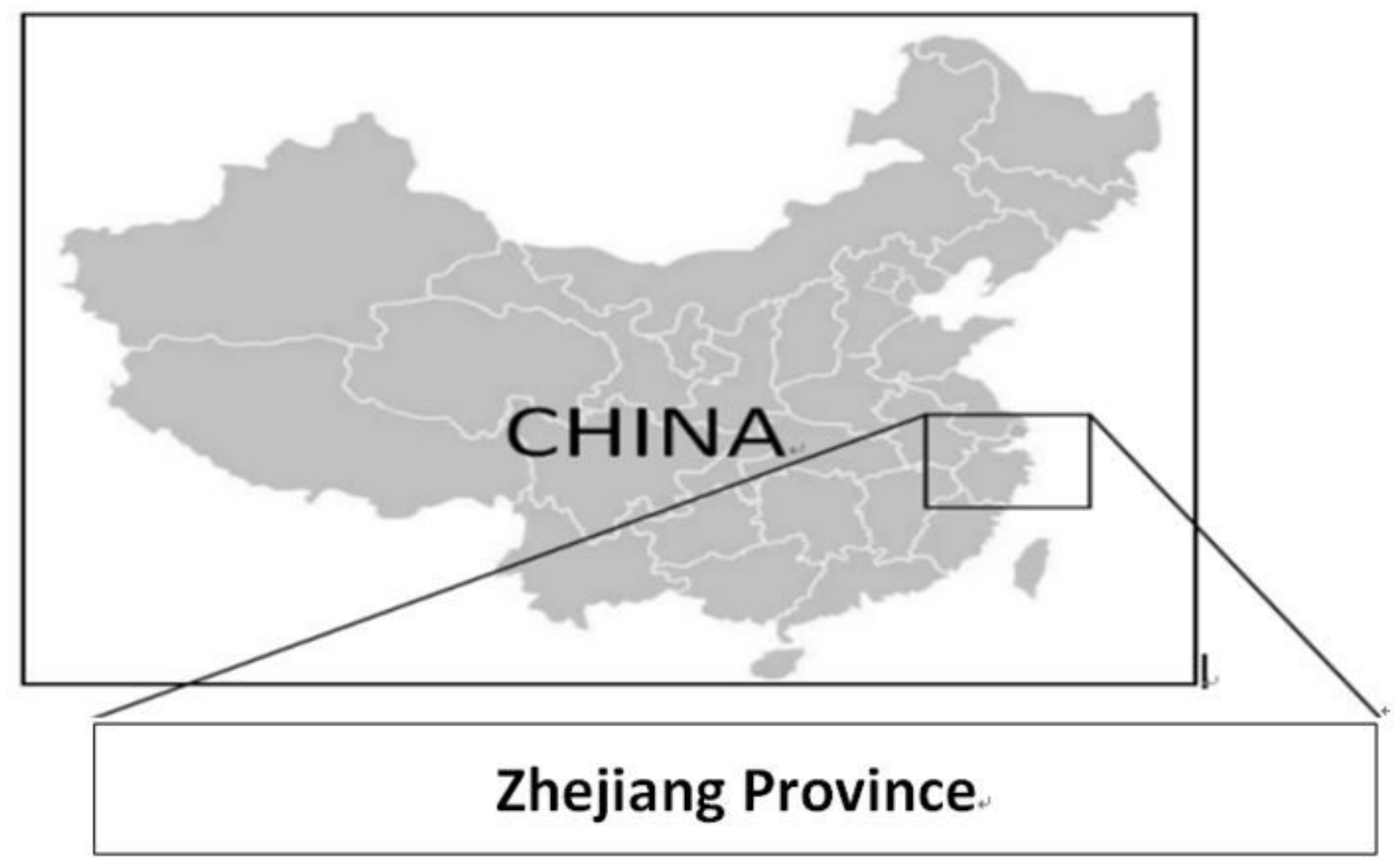

Figure 1

Sampling locations and sites of sediments in the study areas. Note: The designations employed and the presentation of the material on this map do not imply the expression of any opinion whatsoever on the part of Research Square concerning the legal status of any country, territory, city or area or of its authorities, or concerning the delimitation of its frontiers or boundaries. This map has been provided by the authors.

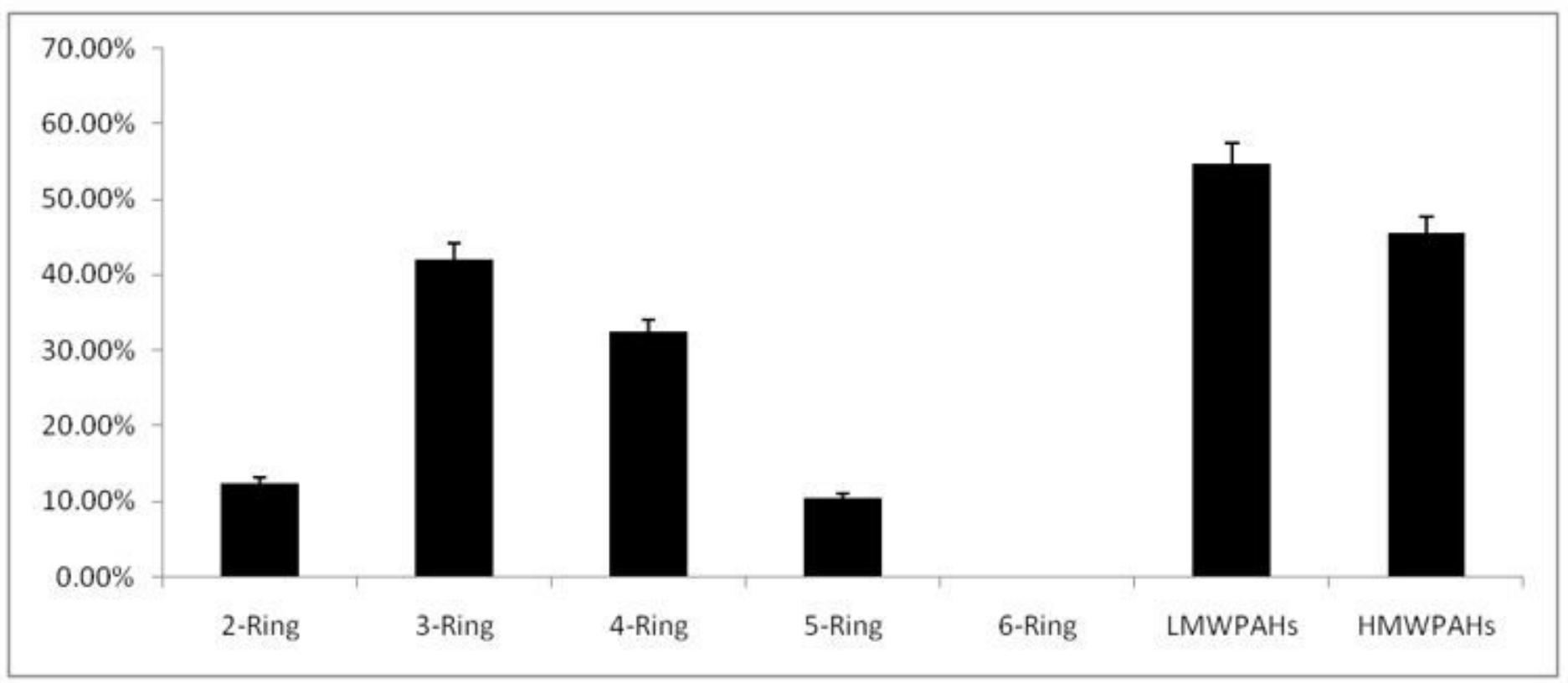

Figure 2 
Mean percentage composition of PAHs (\%) by ring-type in bivalve species samples from Zhejiang Province of China 